\title{
Investigating the Presence of a Nonlinear Exchange Rate Pass Through: A Markov Switching Model Approach
}

\author{
Arshad Hayat ${ }^{1,2}$ and Philip Katz ${ }^{1}$ \\ ${ }^{1}$ Department of International Business, Metropolitan University Prague \\ ${ }^{2}$ IES, FSV Charles University Prague \\ Email: arshad.hayat@mup.cz, philip.katz@mup.cz
}

\begin{abstract}
The main aim of this paper was to estimate the exchange rate pass-through into import prices and the overall inflation rate in the Czech Republic in the light of the Czech National Bank exchange rate intervention policy. We used monthly data from 2000-2017 and used Markov Switching model, as developed by Hamilton (1989), in an attempt to capture the non-linear relationship of the exchange rate-pass through in different regimes of exchange rate intervention vs no intervention in the exchange rate by the CNB.

The paper found the presence of two states in the economy and further found that although the exchange rate $\left(\mathrm{E}_{\mathrm{Czk} / \mathrm{Eur}}\right)$ does not have a significant effect during state 1, the effect becomes significant in state 2 where the pass-through rate into Czech import prices is $42 \%$. This pass-through did not follow into the overall inflation rate. Furthermore, we estimated an $86 \%$ probability of staying in state 2 when the economy is in state 2 . This means that the Czech economy will spend considerably more time in state 2 where the pass-through into import prices is $42 \%$.
\end{abstract}

Keywords: Exchange rate pass through, Markov switching model, inflation rate

JEL Classification: E31, F31, O24

\section{Introduction}

In order to prop up inflation in the country, the Czech National Bank (CNB) decided to intervene in the forex market by depreciating the Czech Koruna (CZK) (Hampl \& Skorepa 2014). The CZK depreciation lead to an increase in the inflation rate and the CNB exited from the intervention by the end of the first quarter of 2017. In this paper, we are going to examine the exchange rate pass-through (ERPT) in the Czech economy.

Exchange rate pass-through is the measure of how changes in exchange rates affect consumer prices, import prices and other domestic prices such as producer prices. Although in recent years economists have studied ERPT more closely than had been done previously there is still much debate on the specific variables that control ERPT.

One of the main contributors to this research, Rudiger Dornbusch (1985), examined the ways in which firms responded to exchange rate shocks by adjusting their mark-up while the market stabilizes at a new equilibrium. Rudiger focused on the relative price effects as well as the speed of adjustment of wages, goods and asset prices and concluded that appreciation should lead to a decline in the price of imports.

Various studies have approached ERPT with different explanations concerning the level of passthrough to consumer and import prices. Choudhri and Hakura (2006) used a data set that contained a 21-year database for 71 countries to examine the effect of inflation on ERPT. Their belief is that a low inflation regime would naturally achieve low ERPT. The tests the hypothesis that ERPT is larger in high inflation regimes. Their findings suggest a "positive and significant" relationship between passthrough and the average inflation rate across regimes.

Other studies have focused their study of ERPT on either developing markets or developed markets as was the case with Ca'Zorzi et. al (2007) and Anderton (2003), respectively. Ca'Zorzi et al. (2007) reviewed what they consider to be the "conventional wisdom" that, in regard to import and consumer prices, pass-through is always higher in emerging markets than in developed markets. The study confirmed that emerging economies do not necessarily have to have higher ERPT than industrialized 
economies assuming the emerging economy has no more than a one-digit annual inflation rate. Additionally, only weak supporting evidence was found to positively link import openness and ERPT.

In a similar study McCarthy et.al (2000) examined the level of pass through over a period of low inflation that more closely resembles the environment of more developed countries. The study concludes that exchange rate shocks do not have a large effect on consumer price inflation and therefore, price stability is a more important focus than currency volatility. Taylor (2000) examined the connection between ERPT and domestic prices in a low-inflation setting. Taylor posits that the lower rate of passthrough could be interpreted as a consequence of the low-inflation regime, which appears as a loss in purchasing power. This argument is developed further to show that "low and more stable inflation should be associated with less persistent inflation." These findings also describe a strong positive correlation between inflation and persistence of inflation, which he believes is suggestive that low inflation itself causes low pass-through.

Anderton (2003) pursued a slightly different line of reasoning by examining how changes in ERPT impact extra-euro area import prices of manufactures. The study outlines two main factors that directly impact the level of pass-through incorporated into euro area manufacturing import prices due to fluctuations in the exchange rate. Anderton concludes that in the long-run $50 \%-70 \%$ of changes to the exchange rate are passed through to extra-euro area imports.

Determining ERPT involves important exchange rate and monetary policy decisions, which are both strongly influenced by the currency in which goods are priced. (Gopinath, Itskhoki, Rigobon 2008) One of the key findings of the recent research was that the difference in pass-through of the average good priced in dollars compared with the average good priced in non-dollars was actually quite large, $25 \%$ and $95 \%$ respectively. This discovery goes against the assumption, found in many important models such as Obstfeld and Rogoff (1995), Betts and Devereux (2000), that the currency of pricing is exogenous.

In recent years, economists have studied the idea of predicting the transmission of ERPT to the domestic inflation of a small, open economy such as the Czech Republic (Babecka 2009) as well as ERPT to domestic prices (Hájek 2014). Babecka uses 11 specifications including some along the distribution chain as previously discussed (McCarthy 2007) to measure ERPT in the Czech Republic. She describes the many varied reasons that reaction of domestic prices to exchange rate shocks is low such as strong competition, pricing to market, currency invoicing, and degree of openness. Babecka reached several conclusions from her research, mainly that there is a high speed of exchange rate shock transmission with $100 \%$ transmission after 6 months. Additionally, her research confirms that in a low inflation environment, pass through is generally low (Taylor 2000). Another observation was that exchange rate shocks created a much larger reaction in tradable goods as compared to non-tradable goods.

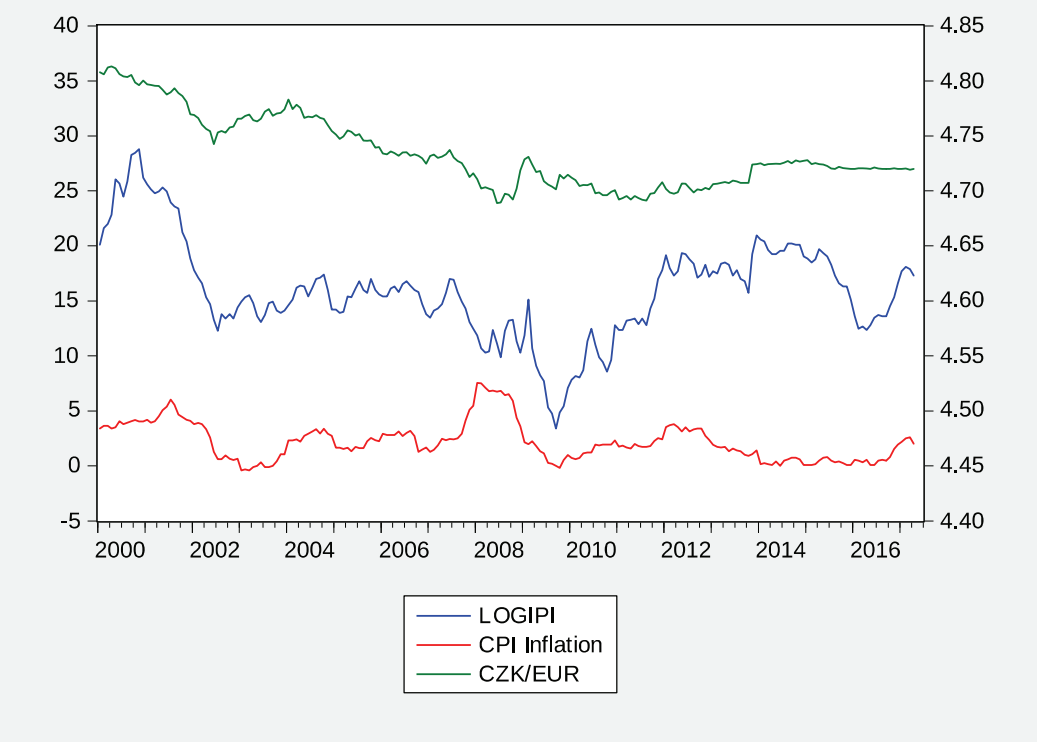

Figure 1. Import price index, inflation and exchange rate 
The contribution of this paper is twofold. Firstly, we estimate the exchange rate pass-through into prices and import prices in the Czech Republic. We also try to investigate if the recent intervention in the $\mathrm{E}_{\mathrm{Czk} / \mathrm{Eur}}$ exchange rate by the Czech National Bank $(\mathrm{CNB})$ has affected the exchange rate passthrough. Secondly, most of the earlier studies that investigated the exchange rate pass-through utilized linear models, however, in this paper, we attempt to capture the non-linear nature of this relationship of ERPT in high vs low inflation regimes as well as different regimes of intervention vs no intervention in exchange rate by the CNB by using the Markov Switching Model developed by Hamilton (1989). The use of Markov Switching model will enable us to better capture the Exchange rate pass-through in the Czech Republic.

The rest of the paper is organized as following: Chapter 2 presents data, chapter 3 presents the methods and models used in the paper, chapter 4 presents the results, and finally chapter 5 concludes the paper.

\section{Data}

This section will discuss the data, sources of data and provide an explanation of each of the variables that were used in this paper. This paper is based on an analysis of the ERPT of the Czech Republic Koruna $(\mathrm{CZK})$ versus the Euro (EU) into inflation and imported goods inflation in the Czech Republic. In order to estimate the ERPT, we used monthly time series data on exchange rate of the Czech Koruna against the Euro, inflation rate, changes in the import price index for the Czech Republic, average monthly Czech real GDP growth rate, oil prices from January 2000 to June 2017. The data for the Czech Koruna against Euro $\left(\mathrm{E}_{\mathrm{Czk} / \mathrm{Eur}}\right)$ and European Union inflation rate was obtained from were obtained from the European Central Bank (ECB), data on inflation in the Czech Republic, import goods inflation and Czech real GDP growth rate were obtained from the Czech Statistical Office (CZSO), and data on oil prices was obtained from the World Bank database.

In table 1, as seen below, is a presentation of the descriptive statistics of data on real GDP growth rate, Czech Koruna exchange rate against the Euro, EU inflation rate, Czech Republic's inflation rate and import price index. Exchange rate and GDP growth are generally considered as strong factors in the increase and decrease of inflation. We can see that the highest real GDP growth of 3.89\% occurred in the $1^{\text {st }}$ quarter of 2004 while the lowest GDP growth of $-2.10 \%$ was recorded in the last quarter of 2008 . Additionally, inflation rate in the Czech Republic reached its peak of $7.55 \%$ in January of 2008 , whereas the lowest mark of inflation rate, $-0.41 \%$ was observed in January of 2003. Foreign country inflation is also considered an important determinant of inflation in the home country. Therefore, in this paper we include European Union inflation as an indicator for foreign inflation. European Union inflation rate is a good indicator because the Czech Republic trades the most with the European Union. The average inflation rate in the European Union was recorded at $0.15 \%$. The minimum inflation rate of $-1.3 \%$ was recorded during the month of March 2011 while the maximum inflation rate of $1.1 \%$ was recorded during the month of January 2015. Further, we included crude oil prices in our model as they are considered another very important determinant for inflation rate. Oil prices were recorded to be the highest at 132.83 USD per barrel and the lowest at 18.52 USD per barrel during the months of July 2008 and December 2001 respectively. The average oil price during the period under observation was 62.954 USD per barrel.

Table 1. Summary statistics

\begin{tabular}{lllll}
\hline Variable & Mean & Std. Deviation & Min & Max \\
\hline Real GDP Growth & 1.116169 & 1.154022 & -2.101726 & 3.89504 \\
E $_{\text {Czk/Eur }}$ & 28.45689 & 3.224929 & 23.893 & 36.324 \\
Inflation & 2.199803 & 1.745222 & -0.4179728 & 7.550823 \\
Import Price index & 100.5115 & 4.557805 & 88.6 & 114.2 \\
Oil Prices & 62.95442 & 30.39325 & 18.52 & 132.83 \\
EU Inflation & 0.1533 & 0.3619 & -1.300 & 1.1000 \\
\hline
\end{tabular}

Source: World Bank databases, European Central Bank, OECD, Own calculations 


\section{Methods and Models}

In this chapter, we describe the methods and models used in order to test for the exchange rate pass through into the inflation rate and import price inflation in the Czech Republic.

\subsection{Augmented Dickey-Fuller Test}

At the core of time series econometrics is the issue of stationarity of a time series and it can strongly influence its behavior and properties. Therefore, before we conduct our analysis, we test for stationary of each of the series used in the paper. We used augmented dicky fuller (Dicky \& Fuller 1981) to test for stationarity of the series.

The following model is used for the ADF test

$$
\Delta y_{t}=\alpha+\beta t+\gamma y_{t-1}+\delta_{1} \Delta y_{t-1}+\cdots+\delta_{p-1} \Delta y_{t-p+1}+\varepsilon_{t}
$$

where $\mathcal{Y}_{t}$ stands for each of the series, $\mathcal{Y}_{t-i}$ the lagged values of the series, $\alpha$ is the intercept and $\beta t$ is used to capture time trend. $\mathcal{E}_{t}$ is error term.

\subsection{Markov Switching Model}

To examine the pass-through of exchange rate fluctuations to inflation rate in the Czech Republic and import goods inflation in the Czech Republic, we use the following Markov switching model (equation 2). The Czech National Bank (CNB) intervened in the Czech Koruna exchange rate against the euro during the period 2013-2017. The exchange rate of the Czech Koruna against the Euro was increased during the period from 24 Czech Koruna per Euro to 27 Czech Koruna per Euro. One of the contributions of this paper is to find out whether the CNB exchange rate intervention has any impact on the exchange rate pass-through. The non-linear nature of the Markov switching model enables us to capture this intervention as well as capturing a possible non-linear ERPT during different regimes of Czech/Euro exchange rates.

Hamilton's Markov switching model (1989) is one of the most widely used non-linear time series models. Also known as a regime switching model, it can define the behavior of a time series when those series are in different states or regimes by using multiple structures. This model is most frequently used to explore complex analysis of patterns by allowing switching between these structures. As described in Kuan (2002), "A novel feature of the Markov switching model is that the switching mechanism is controlled by an unobservable state variable that follows a first-order Markov chain. In particular, the Markovian property regulates that the current value of the state variable depends on its immediate past value. As such, a structure may prevail for a random period of time, and it will be replaced by another structure when a switching takes place." As in this paper we are examining ERPT in different $\mathrm{E}_{\mathrm{Czk} / \mathrm{Eur}}$ exchange rates regimes, the Markov Switching model is the most appropriate model for this study.

This paper uses the following Markov regime switching dynamic regression models to investigate the presence of different states and the variations of ERPT into import prices and consumer prices across those states.

$$
\begin{gathered}
\Delta \pi_{t}^{m}=\mu+X_{t}^{m} \beta^{m}+Z_{t} \varphi_{s}+\eta_{s, t}^{m} \\
\Delta \pi_{t}^{C P I}=\mu+X_{t}^{C P I} \beta^{C P I}+Z_{t} \varphi_{s}+\eta_{s, t}^{C P I}
\end{gathered}
$$

where

$\Delta \pi_{t}^{m}$ is the average monthly log import price changes for the period t

$\Delta \pi_{t}^{C P I}$ is the average monthly log consumer price changes for the period $\mathrm{t}$

$\mu$ is the state-invariant intercept

$X_{t}^{m}$ is the vector of exogenous variables with state-invariant coefficient $\beta^{m}$. These variables include monthly EU inflation rate, average monthly Czech GDP growth rate and monthly changes in oil prices. All these variables are considered to be determinants of inflation in a country.

$X_{t}^{C P I}$ is the vector of exogenous variables with state-invariant coefficient $\beta^{C P I}$. These variables include monthly EU inflation rate, import price index, average monthly Czech GDP growth rate and monthly changes in oil prices.

$\mathrm{Z}_{\mathrm{t}}$ is the vector of exogenous variable exchange rate with state-dependent coefficient $\varphi_{s}$ $\eta_{s, t}^{m}$ and $\eta_{s, t}^{C P I}$ are the error terms. 
Further, for each of the models, we estimate the expected duration of each state and transition probabilities of moving from one state to another. The probability of the current state, J, depends on the previous state

$$
P\left(S_{t}=j \mid S_{t-1}=i, \ldots\right)=P\left(S_{t}=j \mid S_{t-1}=i\right)=P_{i j}
$$

$P_{i i}$ is the probability of being in state $j$ in the current period given that in the previous period the process was in the period $i$. In the end, we will test for significance of the parameters across states.

\section{Analysis of Results}

This chapter presents the results of the models described in the previous chapter.

ADF tests results from equation (1) are presented in table 2 below. We can see in the table that all of the variables except for oil prices are non-stationary at level both with intercept, and intercept plus trend. All of the variables become stationary after taking the first difference. Oil prices are stationary at the level.

Table 2. Augmented Dicky Fuller Test results for the unit root

\begin{tabular}{l|ll|ll}
\hline \multirow{2}{*}{ Variable } & \multicolumn{2}{|c|}{ Level } & \multicolumn{2}{c}{ First Difference } \\
\cline { 2 - 5 } & Intercept & Intercept \& Trend & Intercept & Intercept and Trend \\
\hline CZE INFLATION & -2.305 & -2.475 & $-6.664^{*}$ & $-6.652^{*}$ \\
E Ezk/Eur & -2.281 & -1.549 & $-13.381^{*}$ & $-13.513^{*}$ \\
GDP GROWTH & -2.404 & -2.297 & $-10.195^{*}$ & $-10.191^{*}$ \\
IMPORT PRICE & -2.318 & -2.211 & $-11.553^{*}$ & $-11.557^{*}$ \\
EU INFLATION & -2.293 & -2.558 & $-7.991^{*}$ & $-7.969^{*}$ \\
Oil Prices & $-11.09^{*}$ & $-11.125^{*}$ & & \\
\hline
\end{tabular}

Notes:

*Shows significance at $1 \%$ level

CZE Inflation represents the CPI inflation in the Czech Republic

$E_{C z k / E u r}$ is the Czech Koruna's exchange rate against Euro

GDP Growth is the average monthly Czech GDP growth rate.

Import Price is the Czech import price index

$E U$ Inflation is the rate of inflation within the $E U$

The lags of the dependent variable used to obtain white-noise residuals are determined using Akaike Information Criterion (AIC).

Table 3. Markov switching autoregressive model estimation, log of change in import prices as dependent variable

\begin{tabular}{lll}
\hline Variable & Coefficients & Robust Standard Errors \\
\hline EU Inflation & 0.000143 & 0.0014003 \\
Growth & 0.0015704 & 0.0028623 \\
Oil Price & $0.0002914^{* * *}$ & 0.000112 \\
Cons & -0.0014206 & 0.0036905 \\
& \\
State 1 & \\
Eczk/Eur & 0.015 & 0.351 \\
State 2 & \\
Eczk/Eur & $0.420^{*}$ \\
No of Observations & 207 & 0.085 \\
indicates 90\% confidence level, ** indicates 95\% confidence level, *** indicates 99\% confidence level \\
World Bank databases, European Central Bank, OECD, Own calculations
\end{tabular}

Table 3 presents the results from the Markov Switching model equation (2) where we looked into the ERPT into import prices of the Czech Republic. We can see that the EU inflation rate and Czech GDP 
growth rate both have a very small and statistically insignificant positive effect on import prices in the Czech Republic. Oil prices on the other hand, have a small but statistically significant positive effect on import prices in the Czech Republic.

The impact of the $E_{\mathrm{Czk} / \mathrm{Eur}}$ exchange rate on Czech import prices is estimated differently in different states. We can see from the table below that the $\mathrm{E}_{\mathrm{Czk} / \mathrm{Eur}}$ exchange rate has a very small and statistically insignificant impact on import prices in state 1 while in state 2 the $\mathrm{E}_{\mathrm{Czk} / \mathrm{Eur}}$ exchange rate has a strong positive and statistically significant impact on import prices in the Czech Republic. The 0.420 coefficient of $\mathrm{E}_{\mathrm{Czk} / \mathrm{Eur}}$ in state 2 indicate that a one percent increase in the exchange rate of the Czech Koruna against the Euro leads to an increase of 0.42 percent increase in the prices of goods imported into the Czech Republic.

Table 4 below presents the results from the Markov Switching model equation (3) where we examined the ERPT into inflation of the Czech Republic. We can see that the EU inflation rate has a very small and statistically insignificant negative effect on inflation in the Czech Republic. In contrast, GDP growth has a small but statistically significant positive effect. Further, we can see that oil prices have a very small but significant positive effect on inflation in the Czech Republic. These findings are very much in line with the theory, that domestic economic growth and oil prices have strong positive impact on inflation in the country.

Additionally, import price index has a large, positive but statistically insignificant effect on inflation. The insignificant impact of import prices on domestic inflation is important as this indicates that the ERPT into import prices that we found above has not significantly translated into inflation in the country. The impact of the $\mathrm{E}_{\mathrm{Czk} / \mathrm{Eur}}$ exchange rate on Czech inflation is estimated differently in different states. We can see from the table below that the $\mathrm{E}_{\mathrm{Czk} / \mathrm{Eur}}$ exchange rate has a large but statistically insignificant impact on inflation in the Czech Republic in both state 1 and state 2 . This indicate that the exchange rate pass through has occurred into the import prices in state 2 has not realized as ERPT into inflation.

Table 4. Markov switching autoregressive model estimation, inflation as dependent variable

\begin{tabular}{lll}
\hline Variable & Coefficients & Robust Standard Errors \\
\hline EU Inflation & -0.0074517 & 0.0571222 \\
Growth & $0.1772864^{* *}$ & 0.0705315 \\
Oil Price & $0.0064597^{* *}$ & 0.002918 \\
Import Price Index & 4.491895 & 3.374091
\end{tabular}

\section{State 1}

$\mathrm{E}_{\mathrm{Czk} / \mathrm{Eur}} \quad \mathbf{- 9 . 0 5 2} \quad 9.253$

State 2

$\mathrm{E}_{\mathrm{Czk} / \mathrm{Eur}} \quad-2.736 \quad 3.971$

No of Observations 207

Notes: * indicates $90 \%$ confidence level, ** indicates $95 \%$ confidence level, *** indicates $99 \%$ confidence level

Source: World Bank databases, European Central Bank, OECD, Own calculations

Table 5. Transition probabilities

\begin{tabular}{lll}
\hline Probabilities & Estimate & Standard Errors \\
\hline $\mathrm{P}_{11}$ & $0.509^{* *}$ & 0.359 \\
$\mathrm{P}_{12}$ & 0.491 & 0.359 \\
$\mathrm{P}_{21}$ & 0.134 & 0.219 \\
$\mathrm{P}_{22}$ & $0.866^{* *}$ & 0.219 \\
\hline
\end{tabular}

Source: Own estimation

After determining that the Czech Republic economy has experienced 2 states and that the exchange rate pass-through into import prices has happened only in state 2, we estimated transition probabilities which are presented in Table 5 . P11=0.509 which indicates the probability of staying in state 1 while 
being in state 1 is $50.9 \%$. P12=0.491 indicating an almost $49.1 \%$ probability of moving to state 2 while being in state 1 . In the same way, P21, the probability of moving to state 1 while being in state 2 is $13.4 \%$ and P22, the probability of staying in state 2 while being in state 2 is $86.6 \%$. This indicates, that the economy for a large part tend to stay in state 2 and the Czech import prices experience a significant ERPT.

Table 6 below presents the expected duration of each state the Czech economy is expected to experience. The economy is estimated to stay for 7.439 periods in state 2 compared to 2.037 periods in state 1 . This is further evidence that the exchange rate changes are largely going to get translated into import prices compared to a small period of no such pass-throughs.

Table 6. Expected state duration

\begin{tabular}{lll}
\hline Probabilities & Estimate & Standard Errors \\
\hline State 1 & 2.037 & 1.489 \\
State 2 & 7.439 & 12.142 \\
Source: Own estimation & &
\end{tabular}

\section{Conclusion}

In this paper, we examined the exchange rate pass-through rate (ERPT) to import prices and, in general, to consumer prices in the Czech Republic. Additionally, there was an examination of exchange rate policy, specifically, as regards the exchange rate between the Euro and the Czech koruna, which had been put forth by the Czech National Bank (CNB) and its impact on both inflation and exchange rate pass-through in the Czech Republic.

In order to examine the pass-through of exchange rate fluctuations to import price and consumer inflation in the Czech Republic, we made use of a Markov switching model. We felt this to be the most appropriate model for the study due to the non-linear nature of the MSM which enabled us to observe the CNB's intervention in the Czech exchange rate. The (CNB) intervened in the Czech Koruna exchange rate against the euro during the period 2013-2017. For that period, the exchange rate was increased from 24 Czech Koruna per euro to 27 Czech Koruna per euro. An additional purpose of using the MSM was capturing a possible non-linear ERPT during different regimes of Czech/Euro exchange rates.

The results indicate that while the EU inflation rate and Czech GDP growth have a very small and insignificant effect on ERPT into import prices, oil prices have a small yet significant effect. Although the Czech/Euro exchange rate does not have a significant effect during state 1, the effect becomes significant in state 2 . In fact, in state 2 we observe that the rate of pass-through is $42 \%$. Furthermore, we calculate that there is a $50.9 \%$ chance of switching from state 1 to state 2 and an $86 \%$ chance of staying in state 2 when in state 2. This means that the Czech economy will spend considerably more time in state 2 where the pass-through rate is $42 \%$.

We also found that both GDP growth and oil prices have small, significant effects on ERPT into inflation. However, in both state 1 and state 2 we observe that the $\mathrm{E}_{\mathrm{Czk} / \mathrm{Eur}}$ exchange rate has a large but statistically insignificant effect on ERPT into inflation.

This research is practical both for policy makers, who must understand the macroeconomic environment in which the Czech koruna floats, and businesses, which as exporters and importers are impacted by the changes of the exchange rate. The extent of pass-through to import prices, the effect on domestic prices and the duration of the different regimes are integral knowledge for anyone doing business within the Czech Republic. The understanding of, and with further research, the ability to predict these regime changes is something that should be considered a top priority by policy makers.

\section{References}

1. Anderton, R. (2003), "Extra-Euro Area Manufacturing Import Prices and Exchange Rate Pass-Through", ECB Working Paper No. 219. 
2. Babecká-Kucharčuková, O. (2009), "Transmission of Exchange Rate Shocks into Domestic Inflation: The Case of the Czech Republic", Finance a úvěr-Czech Journal of Economics and Finance, 59, 2009, no. 2

3. Beirne, J. and Bijsterbosch, M. (2009), "Exchange Rate Pass-Through in Central and Eastern European Member States" WORKING PAPER SERIES NO 1120 / DECEMBER 2009

4. Betts, C., and M. Devereux (2000): "Exchange Rate Dynamics in a Model of Pricing-to-Market," Journal of International Economics, 50(1), 215-44.

5. Blanchard, Olivier J., "Price Asynchronization and Price Level Inertia," in Rudiger Dornbusch and Mario Henrique Simsonen, eds., Inflation, Debt, and Indexation, Cambridge, MA: MIT Press, 1983, pp. 3-24.

6. Ca'Zorzi, Michele Ca', Hahn, Elke and Sánchez, Marcelo. (2007) "Exchange Rate Pass-Through in Emerging Markets", ECB Working Paper Series No. 739 / MARCH 2007

7. Choudhri, E. and Hakura, D. (2006), "Exchange Rate Pass-Through to Domestic Prices: Does the Inflationary Environment Matter?", Journal of International Money and Finance, 25, 614-639.

8. Christiano, Lawrence J., Martin Eichenbaum, and Charles L. Evans, "Sticky Price and Limited Participation Models of Money: A Comparison," European Economic Review, 1997, 41, 1201-49.

9. Clark, Todd E., "The Responses of Prices at Different Stages of Production to Monetary Policy Shocks," Review of Economics and Statistics, 1999, 81, 420-33.

10. Dornbusch, R. (1985), "Exchange Rates and Prices", NBER WORKING PAPER SERIES, Working Paper Nc. 1769

11. Gopinath, G., Itskhoki, O. and Rigobon, R. (2008), "Currency Choice and Exchange Rate Pass-through", American Economic Review, March 2010, 100(1): 304-336

12. Hájek, J. (2014), "Exchange Rate Pass-Through to Domestic Prices: The Case of the Czech Republic", (Rigorous Thesis). Charles University in Prague, Faculty of Social Sciences, Institute of Economic Studies. Supervisor: doc. Roman Horváth, Ph. D. Volume: 116612

13. Hampl, M and Michal Skořepa, M (2014) "The transmission of unconventional monetary policy to the emerging markets" (Central Banking Journal 19.11.2014) BIS Paper No. 78 ISSN 1682-7651

14. Jabara, C. L. (2009), "How Do Exchange Rates Affect Import Prices?" Recent Economic Literature and Data Analysis Office of Industries Working Paper, U.S. International Trade Commission No. ID-21 (revised)

15. Kočenda, E and Černý, A. (2014), "Elements of Time Series Econometrics: An Applied Approach, 2nd edition:, Karolinum Press, Prague, 2014

16. Kuan, C.-M. (2002), "Lecture on the Markov Switching Model". Institute of Economics, Academia Sinica

17. Obstfeld, M., and K. Rogoff (1995): "Exchange Rate Dynamics Redux," Journal of Political

18. Economy, 103, 624-60

19. Ocran, M.K., (2009) "Exchange Rate Pass-Through to Domestic Prices: The Case of South Africa". Prague Economic Papers Vol. 19 No. 4 DOI: 10.18267/j.pep.378

20. McCarthy, J (2000): "Pass-Through of Exchange Rates and Import Prices to Domestic Inflation in Some Industrialized Economies". BIS Working Paper, no. 79.

21. McCarthy, J (2007): "Pass-Through of Exchange Rates and Import Prices to Domestic Inflation in Some Industrialized Economies". Eastern Economic Journal, 33(4):511-537.

22. Savoie-Chabot, L and Khan, M (2015) "Exchange Rate Pass-Through to Consumer Prices: Theory and Recent Evidence". Bank of Canada Discussion Paper 2015-9

23. Taylor, J. (2000), "Low Inflation, Pass-Through and the Pricing Power of Firms", European

24. Economic Review, 44, 1389-1408.

25. Taylor, J. B. (2000): "Low inflation, pass-through, and the pricing power of firms". European Economic Review 44 (2000) 1389-1408 


\section{Appendix}

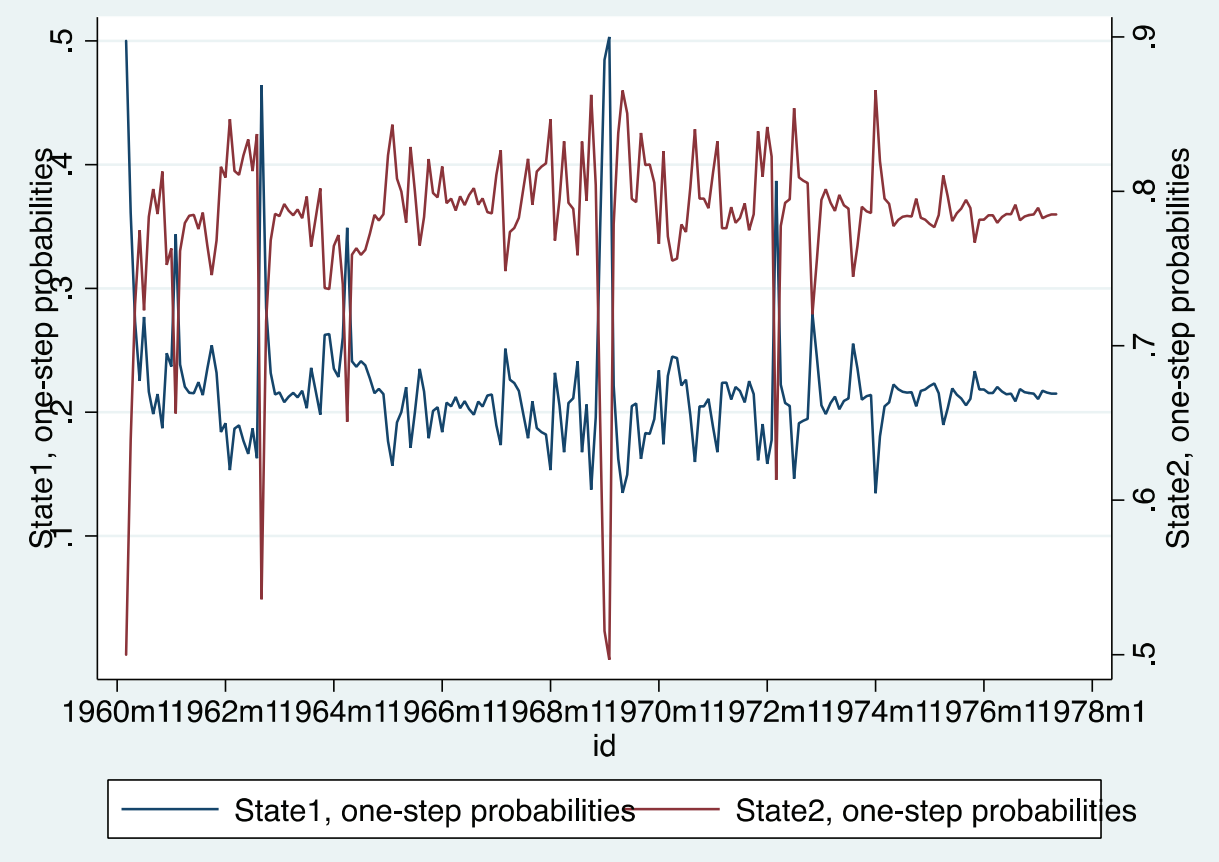

Figure 2. Probabilities of being in each state 